\title{
Curriculum Development of an ICT4D Module in the South African Context
}

\author{
Caroline Pade-Khene \\ Rhodes University, Grahamstown, South Africa
}

\author{
c.khene@ru.ac.za
}

\begin{abstract}
The significance of ICTs in supporting socio-economic development in developing countries is inevitable. As academics of information systems in developing countries, we cannot ignore the need for teaching and building the capacity of our students to become knowledgeable and skilled in Information and Communication Technology for Development (ICT4D) practice and discourse. Furthermore, it is vital to equip our students with the ability to apply their discipline knowledge in addressing some of the ICT discrepancies in current ICT4D practice in their own context. I introduced and teach the ICT4D module to the Honours level course at my university in South Africa. This paper explores the factors that have influenced and shaped the development of the ICT4D module curriculum in the South African context I teach in, using a qualitative ethnographic lens and theoretical study. This provides a practice lens to motivate for and support the introduction of an ICT4D module in tertiary curricula in developing countries.
\end{abstract}

Keywords: Curriculum, Higher Education, Information and Communication Technology for Development (ICT4D), Outcome Based Education, Developing Countries

\section{Introduction}

Information and Communication Technology for Development (ICT4D) is a field that explores how information and communication technologies (ICT) can be used to enable or support development activities in developing countries. ICT4D has now become commonly known as a multidisciplinary field, encompassing information systems, computer science, and socio-economic development studies (Heeks, 2009). The changing nature of the information systems field has also opened the way for other disciplines, such as, health, education, and government. The university I practice in exists in a developing country and is surrounded by marginalized communities and emerging local businesses. The university is surrounded by rural communities and towns confronted with challenging social, cultural, and economic conditions. Understanding the potential and impact of ICT is a core academic area that students can engage with (even before Masters or

Material published as part of this publication, either on-line or in print, is copyrighted by the Informing Science Institute. Permission to make digital or paper copy of part or all of these works for personal or classroom use is granted without fee provided that the copies are not made or distributed for profit or commercial advantage AND that copies 1) bear this notice in full and 2) give the full citation on the first page. It is permissible to abstract these works so long as credit is given. To copy in all other cases or to republish or to post on a server or to redistribute to lists requires specific permission and payment of a fee. Contact Publisher@,InformingScience.org to request redistribution permission.
PhD level), exploring how to use their information systems (IS) skills and beyond to identify and recommend practices to address these challenges in their own country's context. It is essential to understand how the IS discipline can contribute to addressing development challenges faced in South Africa, as government and development organisations continuously explore supporting solutions for development and service 
delivery, and business organizations explore emerging markets in developing countries.

In 2012, I introduced the ICT4D module to the IS curriculum at Honours level for the first time at our university. The aim of this module is to introduce students to the fundamental concepts and discourse of the ICT4D field. Focus is placed on project management and evaluation, toward supporting the sustainability of ICT4D projects in developing countries. Since ICT4D is a multidisciplinary field, the module attempts to integrate concepts of information systems, computer science, and socio-economic development studies. Curriculum development is a diverse activity, which I have come to realize is influenced by many factors, ranging from those based on the individual's beliefs or values, to those that originate from national and international influence. In this paper I use a qualitative ethnographic lens and literature to explore the factors that have influenced and shaped the development of the ICT4D module curriculum in the South African context I teach in. These are based on my experience as a lecturer and past experience as a student and researcher.

To provide contextual background for the concept of knowledge contribution and development in the IS and ICT4D discipline, Bernstein's theory on pedagogic device in the information systems discipline is explored. Subsequently, the methodology that guided the reflection process for the study is outline. My beliefs, values and ideologies around curriculum development are then discussed, followed by a discussion on the categories of curriculum responsiveness that the ICT4D module is informed by or responds to. My response to Outcomes Based Education influence on the module, a requirement in the South African context is then presented. Finally, the conclusion summarizes the findings, with an indication that I plan to reflect on the continuous implementation of the ICT4D module to learn lessons that will continuously shape the module curriculum.

\section{Bernstein's Pedagogic Device in the Information Systems Discipline}

Every module in the information systems discipline is influenced by a set of rules and procedures that determine how we develop our curriculum (Singh, 2002, p. 571). I chose to observe this first at a general level, information systems in general, as this provides a foundation for understanding factors that have influenced the introduction and development of the ICT4D module. Bernstein's theoretical framework (Singh, 2002, p. 571) on the pedagogic device explores how the ensemble of rules or procedures via which knowledge (intellectual, practical, expressive official or local knowledge) is converted into pedagogic communication, such as, classroom talk, curricula and online communication. Bernstein helps us understand the decisions around knowledge that we make in curriculum development and the effect of it, coming to an understanding of what it is we do and why we do it. He attempts to create a mapping between reality and theory. Three main fields of the pedagogic device are identified by Bernstein, which include production, recontextualisation, and reproduction (Singh, 2002). The fields are hierarchically related, as illustrated in Figure 1. Figure 1 also explains how the information systems curriculum development is informed by each of the fields.

- Production - is associated with the production of knowledge. This can be categorised into esoteric knowledge and mundane knowledge. Esoteric knowledge in the information systems discipline originates from specialists and experts in the field, especially those involved in theoretical, as well as practical research. In addition, the information systems discipline is viewed as a professional field. In this case, experiences in the professional environment contribute to the production of new knowledge in the information systems discipline. Professional experience can originate from different professional bodies such as business, government, and development organisations. Furthermore, academics involved in the professional environment as well contribute to this form of knowledge. 


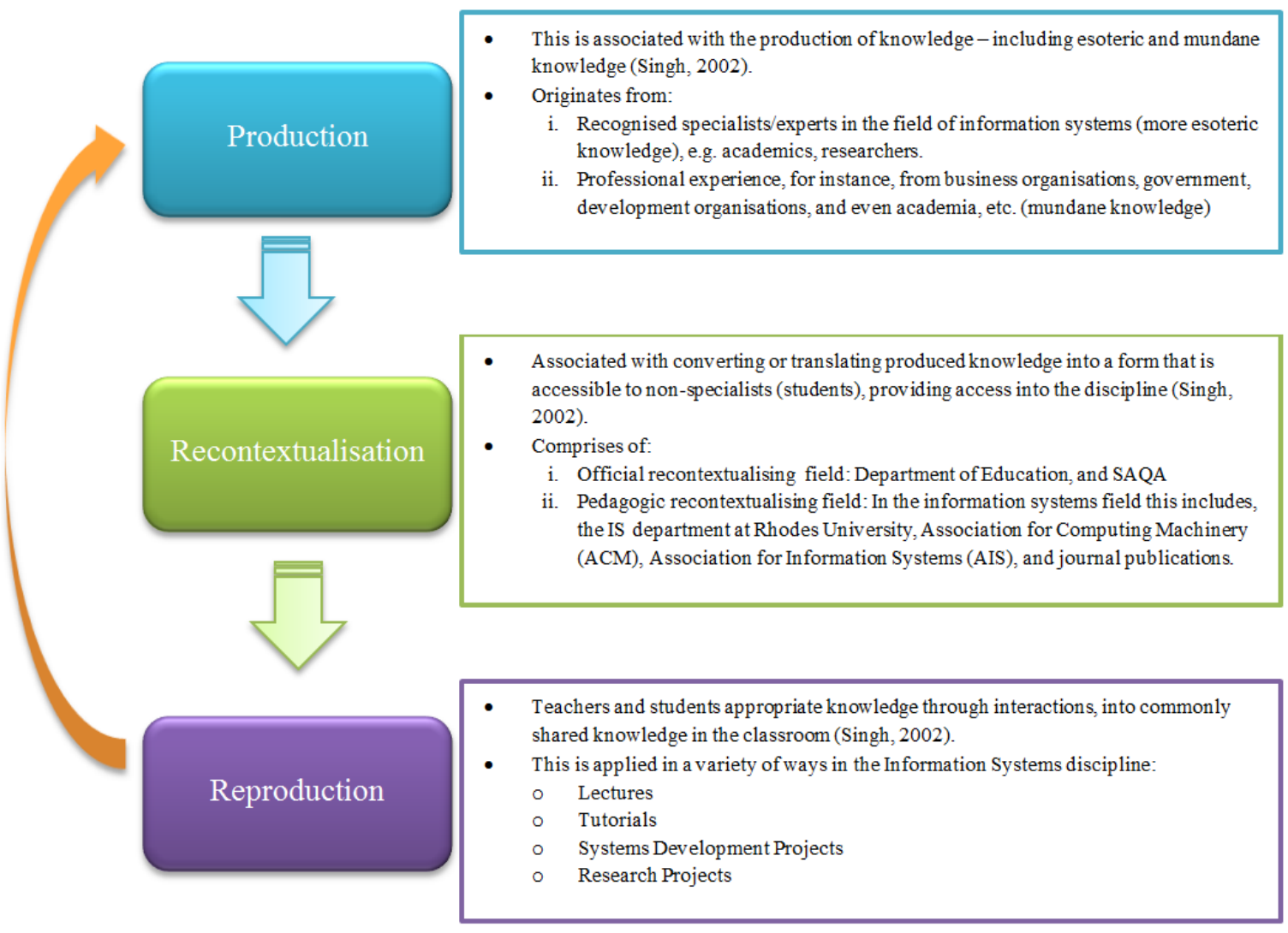

Figure 1: Fields of Pedagogic Device in the Information Systems Discipline

- Recontextualisation - this field is associated with converting knowledge into a form that can be translated by non-specialists, so that they may be enabled to access the discipline. Singh (2002) indicates that recontextualisation consists of two sub-fields, which we interpret in the IS discipline as follows:

i. Official recontextualising field - this includes the National State departments and authorities who formulate macro levels of state policy, which influences the development of curricula across educational institutions at micro level. In South Africa, this includes the Department of Education, Council on Higher Education, and South African Qualifications Authority (SAQA). SAQA is responsible for advancing the objectives of the National Qualification Framework (NQF), a framework that academic institutions are required to incorporate.

ii. Pedagogic recontextualising field - In IS this includes the IS department at my university, who contextualize knowledge for teaching through a curriculum workshop held every year. In addition, international organisations that participate in recontextualising the IS field include the Association for Computing Machinery (ACM) and Association for Information Systems (AIS), who were jointly involved in the formulation of the IS2010 curriculum. The IS2010 curriculum consists of a series of model curricula for undergraduate degrees in Information Systems (Topi, Valacich, Wright, Kaiser, Numamaker, Sipior \& Vreede, 2009). It is built on the foundation of previous international curricula developed and revisions based on trends in the IS field. However, the IS2010 curriculum is not seen as the ideal degree structure for any environment, but rather it provides guidance for core content in the IS field. This series of curricula are consulted and recog- 
nised by IS academia internationally. A key motivation for introducing the ICT4D module in IS, is that the IS2010 curriculum acknowledges that IS is no longer limited to the business domain but now encompasses other domains such as health, government, education, rural development etc. Pedagogic recontextualisation also relies on journal publications and other media (where specialists, researchers and experts publish), to shape and inform curriculum development. This will obviously vary with the IS area studied. Not many textbooks exist in the ICT4D as this is a relatively new field being taught in the IS discipline, hence, the development of pedagogic content relies mostly on journal publications.

- Reproduction - This is associated with the retransformation of texts created in the recontextualisation field, which are appropriated into modes of commonly shared knowledge in the classroom, through interactions with students and teachers (Singh, 2002). In Information Systems, this is applied through various teaching and learning activities, such as, lectures, tutorials/practicals, the systems development project, and the research project. The application of activities obviously varies with the academic level. The ICT4D module is offered at Honours level, and at this stage reproduction of knowledge relies on lectures, class collaborative discussions or debates, and reflective exercises by students. ICT is used to support this reproductive process, through access to material online, and journaling reflections through RUConnected (an online Learning Management System). At the Masters and PhD level, on the other hand, knowledge is reproduced to contribute to the IS body of knowledge. My Masters students apply different aspects of information systems to socio-economic development to reproduce new knowledge associated with the role of information systems in the domain of socioeconomic development - an emerging field in information systems. Our research has also contributed to the teaching content, and researchers are invited to provide a guest lecture to engage the students. The orange arrow in Figure 1 illustrates this production of new knowledge as a cycle. I believe that knowledge is also being produced at Honours and undergraduate level as well, based on discussions in the classroom, which motivate lecturers and students to re-think the application of various concepts in the information systems discipline.

Bernstein's theoretical framework provides a high level foundation for understanding what influences curriculum development and knowledge production in information systems. Placing theory into practice, my beliefs, values and ideologies have shaped the development of the ICT4D module.

\section{Research Methodology}

A qualitative interpretive paradigm is used to guide this study. This philosophy is used to reflect on the factors that have influenced the development of the ICT4D curriculum. An interpretive approach relies on the notion that knowledge is a social construction of reality based on human factors (Walsham, 1995). According to Klein and Myers (1999), research aims to understand human 'thought and action' within their particular contexts. As a lecturer, I aimed to self-reflect and observe the context in which I was shaping the ICT4D module curriculum, within a South African University, in a developing country. Therefore, the research strategy I applied is Ethnography, allowing me to be reflexive, as I am affected and affect the field that qualitative data was collected from, to explore the factors that influence the development of the ICT4D curriculum. Nesbitt (2004) suggests that ethnography can be used as a process to reflect on one's profession, which involves engaged social interaction, hence deepening understanding of the higher education context and curriculum development. I am a lecturer in a developing country, a researcher in 
ICT4D, and a former student of the higher education system in this context; all these have played a role in constructing the ICT4D curriculum and determining aspects to explore. Data was collected using observation of teaching (self-reflective) and the reaction/response/feedback of students, and qualitative evaluation questionnaires from students. Data was analyzed and presented using thematic analysis, and constructively aligning theory and practice in the discussion of the study.

\section{Beliefs, Values, and Ideologies}

My beliefs, values and ideologies on curriculum development originate from my personal experience as a student and lecturer, understanding of my discipline, and cultural values. It is also influenced by the structures and environment in which we practice as lecturers, especially based on the limitations or opportunities provided to us by our university at department and faculty level. According to Toohey $(1999$, p. 45) our beliefs "surface in the language that is used to describe educational goals, in the choice of what is to be taught, in the design of teaching spaces, in the allocation of time within the course, and in decisions about assessment". They can be based on what faculty believes is appropriate, for instance, the 'time' allocated to different module and learning activities, and the 'nature of assessment' (Toohey, 1999, p. 49). Our environment influences our beliefs. My beliefs, values, and ideologies are interpreted in terms of three aspects, which include the cognitive approach I adopt, my argument for vertical discourse in the curriculum, and an adapted curriculum model for the ICT4D module.

\section{The Cognitive Approach}

My beliefs, values, and attitude to curriculum are mainly around the Cognitive Approach. In this approach "the major function of the school or university are to develop the mind, to help students learn how to learn and to provide them with opportunities to use and strengthen their intellectual faculties" (Toohey, 1999, p. 55). This is centered around my belief and approach to teaching and how I believe learning occurs. I believe in a collaborative learning environment that focuses on teaching students 'how we learn or participate in information systems discourse' rather than 'what the students need to know about information systems' (Lujan \& DiCarlo, 2006, Northedge, 2003). I aim to enable student learning in the ICT4D module by engaging with the class through collaborative exercises, such as, problem solving case studies, debates, discussions, and innovative exercises. My philosophy is partly around Vygotsky's theory of cognitive constructivism/learning, that is, proximal development where "potential development is determined through problem solving under adult guidance or in collaboration with more capable peers" (Jarvis, Holford, \&Griffin, 2003, p. 37). As the ICT4D lecturer I am more of a guide, rather than an authoritative figure that disseminates unquestionable information on the discipline to students. Furthermore, I believe in creating a 'safe' environment for the students to feel confident to participate in the class, as well as to engage with the ICT4D content through written and other oral dialogue. The content of the ICT4D module does not cover every aspect of ICT4D, which is quite broad. The module rather focuses on exploring and mastering the concepts of project management, evaluation, and sustainability. In this case, the cognitive approach supports a more focused coverage of a field, providing an environment for cognitive development (Toohey, 1999). Assessment in the ICT4D module is also a cognitively focused approach, where students are required to demonstrate their intellectual abilities they have developed in the module. Assessment exercises include an innovative thinking exercise and a case study application of a theoretical framework. Furthermore, exam questions consist of application based questions.

The cognitive approach, however, has some challenges, which I have experienced as an academic teaching other modules. It is a very time-consuming process, needing a lot more time and resources in the module, which I may be constrained by. However, an advantage is that this module 
is offered at Honours level, where lectures are 2 hours long, students numbers are smaller (hence small-group work), and the cognitive level of students is hopefully higher. Honours level learning focuses more on the development of what Luckett (2001, p. 55) refers to as Experiential Knowledge and Epistemic Knowledge, where learners are at a higher level of needing to critically engage with the discipline content. Furthermore, ICT such as RUConnected provides a supportive tool for access to course material and self-reflection exercises through student journal entries.

Although I believe the cognitive approach fits well for the ICT4D module at Honours, I am conscious that my approach to teaching the ICTD module may vary a bit from how other IS honours modules are taught. Toohey $(1999$, p. 68$)$ indicates that where a module/course approach is different from what would normally be applied in the classroom, students who notice are likely to challenge or resist the difference in the approach. Therefore, it is important the lecturer clearly explains the rationale for the approach at the beginning of the module. Students may benefit from experiencing different approaches applied in the Honours course. Toohey $(1999$, p. 69) indicates that it is important for lecturers to engage in curriculum design for teaching at different academic levels. Some sort of consensus of approaches at Honours level, across the IS department, will benefit the student's learning experience.

\section{Vertical Discourse vs. Horizontal Discourse}

Bernstein differentiates between two structures of knowledge, that is, esoteric knowledge which is associated with vertical discourse, and mundane knowledge, which is associated with horizontal knowledge, as discussed earlier (Singh, 2002). Both forms of knowledge are essential for students to gain, especially in the Information Systems discipline, which is considered a professional discipline. Mundane knowledge is associated with knowledge we gain in everyday experiences. It is context specific, meaning it cannot be applied in other contexts to have the same relevance. Bernstein (2000, p. 157 in Wheelahan, 2007, p. 639) explains that horizontal discourse, which is associated with mundane knowledge, is "likely to be oral, local, context dependent and specific, tacit, multi-layered, and contradictory across but not within contexts." Although as academics in a professional discipline, we do learn from everyday experiences of business organisations and ICT4D projects (for instance, guest lectures in the ICT4D module), we do not rely entirely on these context specific lessons alone. I value providing students with the ability to learn theoretical and conceptual knowledge that underpins the systems of meanings that allow one to "make connections between objects and events that are not obviously related and to "project beyond the present' to a future of alternative world" (Wheelahan, 2007, p. 640). This is referred to as esoteric knowledge, which is associated with vertical (in-depth) discourse.

Vertical discourse allows a student to apply their mind to the structure of the disciplines, which can allow them to transcend knowledge across different contexts and even disciplines. In the ICT4D field, I incorporate more vertical discourse in the reasoning and thinking required for understanding the real-life application of technology in ICT for development. In addition, prior knowledge requires the student has theoretical understanding behind information systems, which they should have attained at 3 rd year academic level. Supporting the development of more esoteric knowledge in the curriculum not only prepares students for industry, but also Masters and $\mathrm{PhD}$, when they are required to engage with the structures of the discipline, at times transcending the boundaries of the discipline to incorporate or apply IS across other disciplines. For example, the ICT for development research field requires that the researcher does not look only at Information Systems or Computer Science, but also at Development Studies, Anthropology, Education, Health, etc. - Transdisciplinarity (Heeks, 2009). Therefore, applying vertical discourse to ICT4D, allows the student to not stay fixed to applying their knowledge in one context (Wheelahan, 2007). Schon (1997) in Barnett, Parry and Coate (2001) indicates that professional fields are now considered as fuzzy domains, incorporating a wider array of fundamental disciplines and sub- 
disciplines and/or professional knowledge-in-action. The information systems discipline is now not solely considered as a discrete body of knowledge, hence the need for esoteric knowledge to transcend across different contexts (Barnett et al., 2001).

\section{A Curriculum Model}

Barnett et al. (2001) indicate that modern curricula can be viewed as an educational project that forms identities founded on three domains: knowledge, action, and self. The relationship between these domains is linked to the student's experience. The 'Knowledge' domain refers to disciplinespecific competencies, and teaching and learning aspects fundamental to developing the information systems specialist (Barnett et al., 2001). The 'Action' domain refers to the skill sets acquired through 'doing', and the 'Self' domain refers to the identity developed by the student in relation to studying the discipline (Barnett et al., 2001). The way I view this model in the ICT4D module is illustrated in Figure 2. In Figure 2, Knowledge, Self and Action all have equal identity in the ICT4D module offered at Honours level. They are interdependent, and support and build on each other to obtain the objectives of the ICT4D module.

Knowledge - the theory around ICT4D, with a focus on project management, evaluation and sustainability, is taught to the students. This foundational knowledge is essential to establish the structure of ICT4D and the underlying motivation and significance in South Africa's developing context. The knowledge encompasses information systems, development studies, and computer science, which is evident in the diverse topics covered in the module.

Self - The aim of the ICT4D module is to develop critical thinking skills in students, who can one day apply these in the management and evaluation of ICT4D projects as information systems practitioners or researchers. Students are required to engage in class discussions and debate on various topics, and keep a self-reflective journal on RUConnected. Barnett et al. (2001) indicate that students begin to internalise systems of management and evaluation around ICT4D, or even information systems in general.

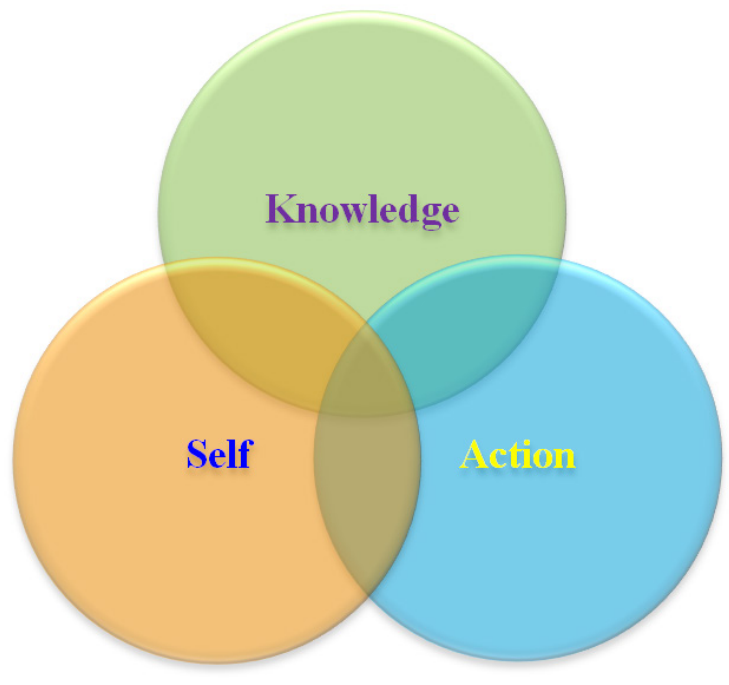

Figure 2. Curriculum: ICT4D Schema

Action - this domain focuses on developing competencies through 'doing', or practical learning activities. Information systems, which would fall under the professional discipline, emphasises a blend of 'relevant knowledge' with 'practical experience' (McKenna, 1982, p. 7 in Barnett et al. 2001, p. 444). The students in the ICT4D module have two practical exercises: 1) Based on case study data, they are required to critically analyse existing ICT4D projects, by applying their man- 
agement and/or evaluation knowledge, and 2) they are required to conduct innovative thinking exercises to determine what will constitute the future of ICT4D, that is, ICT4D 3.0. Action is also associated with obtaining the ability to debate, discuss and present, as students may be future ICT4D researchers or development practitioners who are consulted for their expertise. Barnett et al. (2001) indicate that professional disciplines like Information Systems have always been oriented towards their 'use-value' - created in response to needs of the world. This shifts values from fields that were valued for their own sake, to fields that must demonstrate their relevance to the wider world - in a way I consider this in the ICT4D module. However, I also support Wheelahan's (2007) view that in order to apply knowledge in the world, the student must be able to participate in vertical discourse to understand the deeper meaning of ICT4D knowledge and how it can be applied in developing countries. This explains why I view that each domain of the curriculum model, Knowledge, Self, and Action, have equal identity in the ICT4D module.

\section{Curriculum Responsiveness}

The development of the ICT4D module is informed or responds to various aspects of society. I use Moll's (2004) categories of curriculum responsiveness to discuss these aspects. Moll (2004, p. 3) defines 'curriculum responsiveness' as the extent to which education programmes are meeting the needs of a transforming society. He (Moll, 2004) describes curriculum responsiveness in four senses, that is, economic, cultural, disciplinary and learning-related. An additional curriculum responsiveness sense I also consider is social responsiveness, which was identified by Singh (2002). The various levels of curriculum responsiveness discussed below need to be engaged simultaneously in order to be effective as a whole in the ICT4D module.

Social Responsiveness - This refers to a response to the public good (Singh, 2002). Higher education institutions need to become sensitive to the "development agenda of government and the social and economic needs of African people" (Dowling \& Seepe, 2003, p. 52 in Moll, 2004, p. 14). This does not mean that universities should abandon their core functions, but rather be more responsive to the development needs of the South African economy. Moll $(2004$, p. 14) indicates that: "the pivotal issue in responsiveness to the African context is that the university brings its research, teaching, and, generally, its whole curriculum into engagement with the contemporary realities of Africa, of which the most pressing are processes like rural poverty, underdevelopment, illiteracy, and different forms of cultural domination". The ICT4D module is mainly informed by this category of curriculum responsiveness, by incorporating ICT4D in the IS curriculum, and motivating for further research at Masters and $\mathrm{PhD}$ level, in this field.

Economic Responsiveness - this refers to a response to the demand for high qualifications, knowledge and skills in information systems by the labour market in the South African economy (Moll, 2004). The information systems department at my university has an Advisory Board consisting of CIOs (Chief Information Officers) from leading business organisations, and Information Technology consultancies in South Africa that provide advice on needed skills, or comment on shifts in our discipline. A meeting was held in 2011, and the ICT4D module was presented as a possible module to offer at Honours level. The Advisory Board values our university IS graduates for their ability to present and speak well, as well as their analytical skills, which they encourage our department to continue developing in our students. Furthermore, they have been drafted by government at times to work on IS projects that can be implemented in rural areas. Equipping students with the knowledge to work in such environments is essential to their business, and hence they approved of the module. Our graduates also end up working for government. However, our Advisory Board currently only has one representative from government compared to seventeen other business organization representatives, which is unfortunate, as other public or non-profit organisations should have a key 'say' in economic responsiveness in the public sector. As a result, the ICT4D module at Honours levels is not recognised as a core module, 
but rather an elective module which some students are reluctant to take because of a lack of awareness of its relevance.

Cultural Responsiveness - refers to a response to the "cultural diversity of students and society by incorporating multiple cultural reference points that acknowledge diversity and constitute various alternative learning pathways for students" (Moll, 2004, p. 5). I use Moll's quote because he clearly delineates between responsiveness to the culture of students we teach and also responsiveness to the 'African cultural way of doing things' - African solutions for African problems. I focus on the latter, specifically for the ICT4D field, as information systems needs to be contextualised for application in marginalised or rural communities of developing countries. What works well in business or developed countries does not work as effectively in marginalised or rural contexts of developing countries, hence why a number of ICT4D projects are not sustainable or fail altogether (Avgerou \& Walsham, 2000; Heeks, 2005; Thompson, 2008; Zheng, 2009). The discipline should be sensitive to African realities and how IS can be recontextualised for developing country contexts.

Discipline Responsiveness - refers to a response to the nature of the underlying IS discipline, in terms of the way knowledge is produced and the way students are educated (Moll, 2004). As academics, we are required to keep up to date with trends in our discipline. We also consult the IS2010 curriculum for information systems, a global curriculum development collaboratively with members of the Association for Information Systems, and the Association for Computing Machinery (ACM). However, we still have to be sensitive to the SA context when reviewing this global curriculum. Examples of shifts in the discipline indicated in the IS2010 curriculum that we need to be responsive to include a shift of focus in the discipline on how to manage information vs. developing systems that create (and manage) information. Emerging subject topics/modules focus now on information management and planning due to increasing amounts of information in society. Another example is less concentration on programming or implementation skills, and more focus on producing an IS professional who will usually be involved in IS Analysis and Design, rather than programming. Ultimately, the IS professional expected is a critical analyst, which the ICT4D module (as well as other IS modules) aims to achieve. As stated earlier, another key motivation for introducing the ICT4D module in IS is that the IS2010 curriculum acknowledges that IS is no longer limited to the business domain, but now encompasses other domains such as health, government, education, rural development, etc. According to the IS2010 curriculum, academics who teach these domains are expected to teach the following domain fundamentals: a) general models of the domain, b) key specialisations within the domain, and c) evaluation of performance within the domain. All these fundamentals are covered in the ICT4D module topics.

With regard to disciplinary responsiveness, Moll (2004, p. 12) describes the debates that have emerged in South Africa, about International influence on the curriculum. Moll (2004, p. 12) indicates that "university courses need to become less embedded in and referenced against international academic debates, and more responsive to putatively unique African realities". There are unique African patterns that can only be understood and are embedded in evolving unique African epistemologies - there is a need to equate cultural and disciplinary responsiveness, which I have attempted to do in the ICT4D module. In this case, ICT4D research can adopt some western models, and customize, adjust or revise for African contexts. A lot of knowledge produced in the ICT4D field through research is based on this premise. Part of the content covered in the ICT4D module was developed from this knowledge; the readings covered in each lecture topic are from research publications.

Learning Responsiveness - refers to a response to the learning needs of students based on how accessible the discourse in the ICT4D discipline is to them, and adopting assessment techniques that are understandable to them (Moll, 2004). Aspects considered in learning responsiveness in- 
clude: "lecturing creatively, preparing facilitating discussions, helpful [module] evaluations, and overcoming resistance to learning and building trust with students". These aspects are essential for the progressive development of the ICT4D module as an emerging course in the IS curriculum. I have incorporated these aspects within the teaching and learning activities and assessment of the module, especially given my teaching philosophy is around engagement and enabling critical thinking for life-long learning. I aim to teach students how to critically think of the application of information systems to human development initiatives, exploring enabling and constraining factors that information systems professionals in developing countries should be aware of. I focus on ensuring students achieve life-long skills which they can apply in their professions, beyond the business organisation context, to social/cultural/economic contexts. To facilitate learning responsiveness, I conducted a module evaluation (through observation and focus group discussion) prior to the module, during the module, and at the end of the module, to gauge student feedback and adopt any changes, where needed. The focus was also to be informed of what worked best and what could be improved for the continuous development of the module (during the module, as well as, teaching the module in future years) based on learner responses. Post-learning evaluation was quite an informative exercise, and it revealed aspects of the module that worked well, and encouraged student engagement, as well as those that did not work well. Students provided very positive feedback about meeting their expectations of the module:

"My expectations were highly met, over and above..." "I enjoyed the guest lecture specifically..."

"I found the module very insightful, like the case studies we went through...ummm...for me that was the hands on experience even though we didn't get to go to the field...but the people that came and spoke to us, we saw what they went through, so for me it was very insightful..."

"I think it was the best course I had ever had in the university"

"I think some of us took it for a credit or for our research [those doing ICT4D research], but it was over and above our expectations, it was insightful"

"An eye opener, it was really interesting... and now I have a better understanding of ICT4D ...the fact that it was intimate [we had to discuss in class] really worked in our favour because we were really able to speak openly about these issues, and there are issues that are relevant to us all so I really enjoyed it... the fact that it was very interactive, so we got to hear different views come out.....sounds like you are in a lecture but not really a lecture, because it was engaging, it was a discussion, that's what it was, and that was a really nice aspect"

\section{A Response to Outcomes Based Education (OBE)}

Major social and economic changes lead to a change or shift in curriculum, as curriculum exists in the context of these changing conditions (Luckett, 2001). These social economic conditions result from changes in society at a national level and international level. As South Africa rejoined the international community post-apartheid, higher education has now had to operate in a global, as well as, local environment (Boughey, 2004; Gibbons et al., 1994; Jansen, 1998; Luckett, 2001). A new global economy that has emerged, with the introduction of information and communication technology, has resulted in a new economy based on 'information and knowledge', rather than on 'raw material and the capacity to process them' - Globalisation (Boughey, 2004). In this case, a higher demand for a highly skilled workforce has emerged, based on the need to meet the demanding requirements of a globalised economy. Gibbons et al. (1994) identify a shift on focus of knowledge that higher education institutions may have to accommodate, requiring a shift in 'Mode 1' knowledge that focuses on knowledge produced within traditional disciplinary 
boundaries, to 'Mode 2' knowledge which is characteristically transdisciplinary, transinstitutional and heterogeneous.

The South African government focuses its efforts nationally on transformation, with higher education being one of the main targets, as they enrol and produce future graduates who will one day contribute to the economy. The government also established the South African Qualifications Authority (SAQA), which is responsible for the National Qualification Framework (NQF), in terms of setting standards around this framework and the assurance of quality to meet these standards (Boughey, 2004; Ensor, 2004; Luckett, 2001). This resulted in the introduction of the Outcomes Based Education (OBE) system, closely linked to the NQF. The OBE is centred around 'what learners should be able to do' rather than 'what learners should know', obviously with an impact in the way we teach students (Boughey, 2004, p. 8). Knowledge is now more associated with 'use-value' to society, than disciplinary knowledge - emphasis is now placed on 'doing', rather than 'knowing' (Silver \& Brennan, 1998 in Barnett et al., 2001). From my experience, this system has been met with a lot of resistance, due to a number of factors. Universities are faced with the pressure to review their curriculum to be in line with OBE requirements.

\section{Challenges associated with OBE}

OBE affects the educational system, including primary, secondary and tertiary education levels. Authors in literature discuss different views of the challenges associated with OBE. Jansen (1998) proposes two levels of analysis of the challenges with OBE, 1) Technical prerequisites needed to implement OBE are not in place, such as resources, strategies, time, etc. and 2) Political, where the government has their own agenda with OBE mainly as an act of 'political symbolism'. The challenges I discuss here are those that have stood out for me, those that I have come to belief can negatively influence the development of the curriculum in my discipline.

\section{a) $O B E$ should not be seen as a panacea for economic growth and pedagogical problems}

Government imposes a lot of pressure on universities to address the economic and social needs of the country, through their National Qualification Framework. The National Curriculum Development Committee indicated in 1996 that South Africa's inability to generate economic growth is largely related to the lack of relevant skills (Jansen, 1998). However, Jansen (1998, p. 324) argues that there is no evidence in 80 years of curriculum change literature that stipulates that curriculum response to economic conditions has 'significant social or private benefits'. I believe education does play a role in supporting socio-economic development in South Africa, which the ICT4D module I teach aims to contribute to. However, education is not enough, because there are other social, cultural, economic, and political issues that need to be addressed. For instance, from my personal experience as a researcher, key findings of my research have not been easily implemented at a larger scale because of a reluctance by stakeholders to change the human development process. Development is not a simple matter that can easily be addressed by the increased supply of skill.

\section{b) A lack of direction on how to implement $O B E$}

Even though SAQA is so convinced of an outcome-based approach to integrate generic transferable skills into the South African curriculum to ensure the relevance and applicability of the curriculum, it does not clearly state or have the expertise to state how this will be done (Jansen, 1998; Luckett, 2001). As a result, issues have emerged which providers/lectures are left to figure out, such as "how the different disciplinary, cognitive and students' developmental contexts affect the meaning of generic skill; how students will learn to transfer these skills from familiar to unfamiliar contexts; and how a range of ways of knowing, which are not always compatible with the epistemology of the content in which the skills are to be embedded, are to be fostered and assessed" (Luckett, 2001, p. 52). As an academic, I have to attempt to comprehend how this could 
be applied, or make sense in the modules I develop, and especially determine how my module is integrated with other modules offered in the Information Systems discipline. I discuss my proposed approach later in the next section (considerations for applying OBE).

\section{c) An ignorance of the complexity required to create capacity - vertical discourse}

One cannot achieve the outcomes pre-set in a module/course by directly teaching to the outcomes (which are aligned with skill needs in the economy), as it can ignore the complexity needed to understand the theoretical or conceptual foundations that shape the discipline; some of which go beyond pre-set outcomes that are usually limited to particular contexts (Knight, 2001; Wheelahan, 2007). OBE in this sense is related to the development of mundane knowledge, associated with horizontal discourse. This has its limitations as the 'style of reasoning' and thinking related to understand the structures of a discipline are reduced - a lack of vertical discourse exists. As a result, Bernstein indicates that the application of OBE type approaches transforms the nature of knowledge, as it is delocated from vertical discourse thinking, and relocated towards horizontal discourse that is limited to particular working contexts (Wheelahan, 2007). This actually negatively impacts on the development of Mode 2 knowledge which the government aims to attain. This is so, because the inability of students to apply critical thinking and reasoning within the structure of their own discipline, limits their ability to incorporate the perspective of other disciplines in addressing work or societal problems which are quite transdisciplinary in nature - a key characteristic of the ICT4D field. Theory is needed to understand what is going on across disciplines, as well as, in real life situations. Focusing on outcomes, does not give the student skills to learn the principles and rules associated with the decisions they make after graduation in the workplace or in society. OBE is essentially 'derailing the social justice strategy' (Wheelahan, 2007). Reasoning is essential to make effective decisions in events or activities.

\section{d) Planning is 'tight-coupled', not allowing for flexibility of outcomes}

Knight (2001) argues that complex learning cannot be easily reducible to precise statements that predict what the outcome will be of a module/course. In curriculum development, planning cannot be straight forward and 'tight-coupled', not allowing for the flexibility of outcomes that can emerge in the classroom. Knight (2001) and Wheelahan (2007) advise that we need to understand that higher education is about complex learning. It is not just so simple to set particular outcomes (as OBE suggests) that the lecturer has to stick to. What about unintended outcomes that emerge in the classroom, that are also desirable as part of the learning experience (Hussey \& Smith, 2003)? For instance, a student may explore or ask a question on a particular topic in the ICT4D module, which may lead them to explore other areas of ICT4D which will support their understanding of a particular topic. This is why Jansen (1998) argues that specifying outcomes in advance is quite 'anti-democratic', not allowing for the flexibility of emerging outcomes. I have specified outcomes in the ICT4D module specification document (see the Appendix); however, I still allow a guided 'corridor of tolerance' for other learning outcomes that may emerge during the course of the module in classroom discussions, debates, and self-reflective exercises.

\section{Considerations for Applying Outcomes Based Education}

Given the above challenges, OBE is often met with resistance by academics. However, I believe that if OBE does not concentrate on being too instrumental, it just may work. The concepts and principles behind it may actually be essential in today's society, but the key is that it is implemented appropriately. Students that come into university, come with the expectation of one day obtaining a degree that would make them employable. They want to feel that they could use the knowledge they obtain in university, in the workplace or society. I in fact had the same expectation as a student in 1st year many years ago. I did not just want to obtain knowledge of the IS dis- 
cipline, I also wanted to know what I could do effectively with that knowledge, hence the idea behind OBE.

In my investigation of how I may develop my curriculum to meet the expectations of OBE, I consider three different theoretical perspectives: 1) Luckett's (2001) framework on 'An Epistemically Diverse Curriculum'; 2) Biggs' (1999) framework on 'Constructive Alignment'; and 3) Hussy and Smith's (2003) theory on 'Emergent Learning Outcomes'.

\section{An Epistemically Diverse Curriculum}

Luckett (2001) provides a model to inform and frame the diverse knowledge needs of South Africa. I appreciate his model because it illustrates the different concentrations of knowledge we can expect our students to develop during their academic years. It acknowledges the need for vertical discourse or esoteric knowledge as foundational knowledge in the discipline, and how this knowledge can be translated and applied in the work environment or society. He presents four quadrants, as four ways of knowing. The combinations of the knowledge quadrants differ with the nature of the module I teach, the students, as well as the context. Figure 3 illustrates the combination of quadrants for the ICT4D module that is offered at Honours level. Each quadrant is essential in the ICT4D module, however, the green shading indicates the levels of concentration for each quadrant.

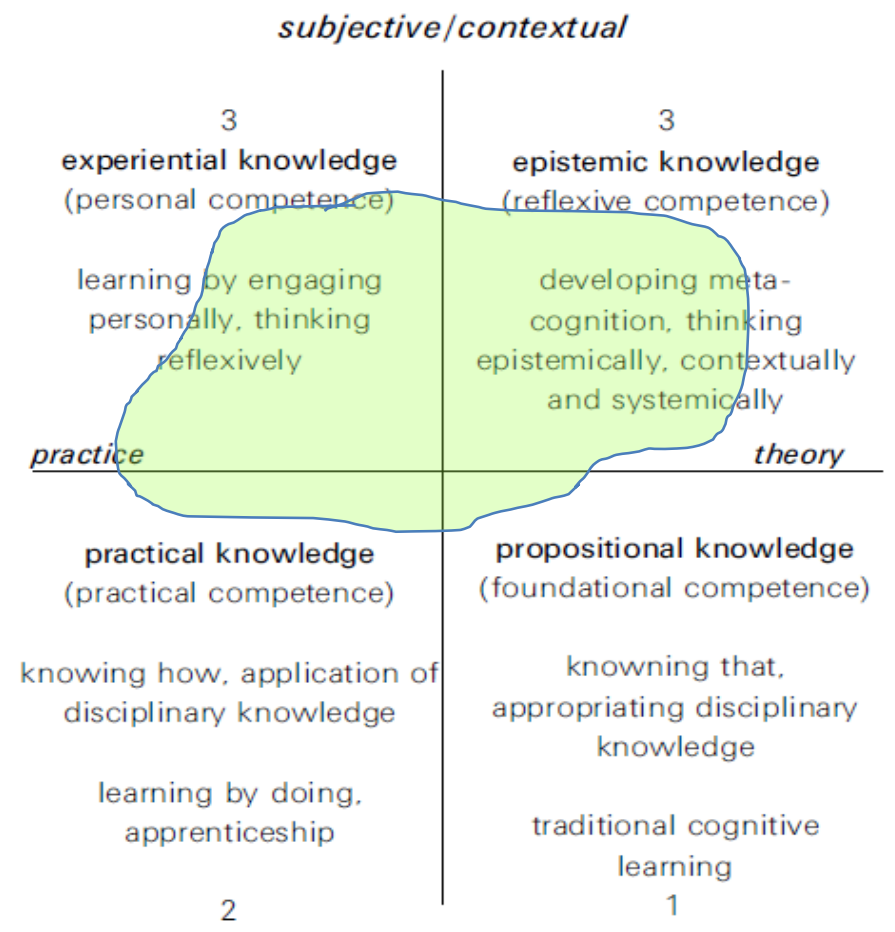

objective/reductionist

Figure 3. An Epistemically Diverse Curriculum for the ICT4D Module (adapted from Luckett, 2001)

Quadrant 1. Propositional Knowledge - refers to foundational knowledge of a discipline, often associated with Mode 1 knowledge. Higher education is often initiated with propositional knowledge, as students are inducted into the theory that underlies the discipline. The ICT4D module requires that students have prior knowledge from 2 nd and 3rd year level information systems, where they would be introduced to the fundamental concepts and practice in the infor- 
mation systems discipline. However, given ICT4D is a new domain incorporated into their information systems study, they have to also be introduced to the concepts and structure of the ICT4D field, bearing in mind that they will revisit IS concepts already covered in their previous years of study, for example, project management, analysis, and design. This is illustrated in Figure 3 as a slight concentration in quadrant 1.

Quadrant 2. Practical Knowledge - context is provided for the application of propositional knowledge, and the performance of practical tasks. Prior learning in IS required for the ICT4D module consists of practical experience in project management, analysis, design, etc. The students are required to apply their knowledge of IS concepts in these topics, practically in evaluating ICT4D project cases studies. Furthermore, students are required to demonstrate their ability to engage and apply ICT4D concepts they would have been introduced to. For instance, they are required to assess the strengths and weaknesses of an existing ICT4D project using a framework for ICT4D project management, and hence provide recommendations for sustainable project management practices.

Quadrant 3. Experiential Knowledge - this is obtained when students are encouraged to engage with the discipline through self-reflective exercises. Luckett $(2001$, p. 56) refers to this as a "critical epistemic shift', where students move away from viewing knowledge as authoritative (transmitted by the lecturer alone) to socially constructed (based on their own knowledge and judgement which is contextually contingent). This is essential and key in the ICT4D module, as different interests and perspectives can be shared in the learning process through discussion and debate in the classroom. This creates an atmosphere of "self-motivation, self-confidence, innovation and creativity, social sensitivity, negotiation, mediation and leadership skill" (Luckett, 2001, p. 58), all key to understanding and exploring how ICT can support development in South Africa. In the ICT4D module, I also act as a mentor or mediator in the learning process when I require the students to engage in debate and discussions based on readings selected for the module topics. Furthermore, each student is required to keep an on-going self-reflective journal for each topic covered in the module, which is assessed as part of formative assessment. As the lecturer, I assist the students to process and reflect on ICT4D topics as part of the learning process.

Quadrant 4. Epistemic Knowledge - this knowledge allows one to think of how one thinks (metacognition) and to recognise the assumptions and limits of theories, especially within their own discipline, to recommend alternatives (epistemic cognition) (Luckett, 2001, p. 57). From quadrant 3 , students shift to a higher level of reflexivity. Even though the same teaching and learning activities apply, such as debates, discussions, and self-reflective journals, students are given a safe space to explore and rethink the structure of their disciplines in terms of values, ethics, and responsibility, and recognise the other ways of knowing to address problems in society or the workplace. For instance, ICT4D is multidisciplinary, which includes the disciplines of information systems, computer science, development studies, anthropology, and any other domain specific needs such as education, health, agriculture, etc. The student is required to consider the structure of the information systems discipline, but also incorporate the structures or knowledge of other disciplines such as development studies, to understand how ICT can support development in South Africa. Here, students can begin to see the connections between other disciplines, and apply transdisciplinary approaches to investigating ICT4D in South Africa. This type of knowledge will even become more prominent at Masters or $\mathrm{PhD}$ level research, which we also prepare our Honours students for.

An epistemically diverse curriculum evidently shows how a student can still maintain esoteric knowledge or vertical discourse, but most importantly use this knowledge to develop generic transferable skills required for socio-economic development. If government and academics can understand OBE in terms of this framework, tensions may possibly be reduced between both parties. 


\section{Constructive Alignment and Emerging Outcomes}

Key to the relevance of the curriculum for the ICT4D module is that an alignment exists between curriculum objectives, teaching and learning activities (TLAs), and assessment tasks (Biggs, 1999). Objectives highlight what the student is expected to learn in the module, teaching and learning activities are used to encourage or enable students to engage with the ICT4D content in the way the objectives require, and assessment tasks indicate whether or not the learning has been successful (conveying to students what they need to learn) (Biggs, 1999). Where assessment tasks require or elicit lower levels of cognitive abilities than that indicated in the objectives, students become reluctant to engage with the discipline in a deeper manner (Biggs, 1999). It is this lack of alignment that is a major reason students adopt a surface approach to learning, which I aim to avoid as the ICT4D module focuses on the development of experiential and epistemic knowledge. Therefore, careful planning in aligning objectives, TLAs, and assessment tasks is essential.

Each lecturer in the information systems department is required to develop a knowledge document, known as a Module Specification Document for each module they teach. This document specifies the objectives of the module, TLAs and assessment criteria. It provides detailed information on the module including: an overview of the field, credit value, assumptions of prior learning, critical and specific outcomes, teaching methods, module content, resources, student assessment criteria and methods, and module evaluation. This document is distributed to students at the beginning of the module, to guide them on what they should expect in the module, and how they will be assessed. Given a collaborative learning approach is applied in the ICT4D module, students are informed of this expected class activity at the beginning of the module, through the module specification document and an introductory lecture at the beginning of the module. Students should be informed of why the lecturer is using a non-traditional (collaborative) lecturing approach and how best they can engage with the ICT4D concepts (Knight, 2001; Spruell \& Blanc, 1992).

When setting curriculum objectives (intended objectives) in a constructively aligned curriculum, it is essential that the curriculum accounts for emerging learning outcomes. Lecturers need to plan and apply a 'corridor of tolerance' in the classroom for learning outcomes that emerge as the student engages in the class - for 'learning moments' to occur (Hussey \& Smith, 2003). Allowing for emerging outcomes allows the student to engage deeply and significantly with the subject material. Students begin to interact deeply with the module, in a safe space where they can exercise their interests, insights and reflections. However, using my expertise and background in ICT4D, I have to ensure that I maneuver the students appropriately in the right direction, so that we do not lose direction in the module. I apply the following practices in the presentations, debates, and discussions that allow for emergent outcomes:

- Embark on topics that originate from class discussions or questions (Hussey \& Smith, 2003).

- Beware of disruptive and dysfunctional learning outcomes - maintain direction in the module, this may be aided by listing a clear set of content that will be covered in the module (Hussey \& Smith, 2003).

- Students need to know at the beginning of the module, what kind of learning is intended, so as to reinforce a rich learning environment (Knight, 2001). I communicate this clearly during the introductory lecture. 


\section{Conclusion}

Curriculum development of the ICT4D module has shown me how the process of developing curriculum relies on or is influenced by a variety of factors. Bernstein theory on pedagogic device explains how we make the decisions around knowledge in our discipline generally, and the effect of it, through the fields of production, recontextualisation and reproduction. From my individual perspective, I have explored my beliefs, values, and ideologies through identifying the cognitive approach as my favoured approach to curriculum development, valuing vertical discourse in my curriculum, and identifying the equal significance of Knowledge, Self, and Action in my curriculum model for the ICT4D module. Furthermore, I have identified that the ICT4D module is informed by and responds to the following categories of curriculum responsiveness, all of which should be engaged simultaneously in order to be effective as a whole in the ICT4D module: social responsiveness, economic responsiveness, cultural responsiveness, and discipline responsiveness. Finally, my response to OBE in the South African context is that I can clearly identify challenges associated with it; however, I do not think we should throw it out totally. Considering the theoretical perspectives and application of Luckett's (2001) framework on 'An Epistemically Diverse Curriculum', Biggs' (1999) framework on 'Constructive Alignment', and Hussy and Smith's (2003) theory on 'Emergent Learning Outcomes'; OBE may actually be applicable in the ICT4D module, and other modules offered in the Information Systems discipline. Taking into consideration the above aspects of curriculum development, I continuously reflect on the implementation of this core module in the Honours class, to learn lessons that will continuously shape the module.

\section{References}

Avgerou, C., \& Walsham, G. (2000). Introduction: IT in developing countries. In C. Avgerou \& G. Walsham (Eds.), Information technology in context: Studies from the perspective of developing countries (pp. 1-8). Aldershot; Burlington, VT: Ashgate Publishing.

Barnett, R., Parry, G., \& Coate, K. (2001). Conceptualising curriculum change. Teaching in Higher Education, 6(4), 435-449.

Biggs, J. (1999). What the student does: Teaching for enhanced learning. Higher Education Research \& Development, 18(1), 57-75.

Boughey, C. (2004). Higher education in South Africa: Context, mission and legislation. In S. Gravett, \& H. Geyser (Eds.), Teaching and learning in higher education (pp. 1-31). Pretoria: Van Schaik.

Ensor, P. (2004). Contesting discourses in higher education curriculum restructuring in South Africa. Higher Education, 48, 339-359.

Gibbons, M., Limoges, C., Nowotny, H., Schwartzman, S., Scott, P., \& Trow, M. (1994). The new production of knowledge. The dynamics of science and research in contemporary societies. London: Sage Publications.

Heeks, R. (2005). ICTs and the MDGs: On the wrong track. UK Development Studies Association Conference, Open University, Milton Keynes. 7-9.

Heeks, R. (2009). The ICT4D 2.0 manifesto: Where next for ICTs and international development? Manchester: Institute for Development Policy and Management.

Hussey, T., \& Smith, P. (2003). The uses of learning outcomes. Teaching in Higher Education, 8(3), 357368.

Jansen, J. D. (1998). Curriculum reform in South Africa: A critical analysis of outcomes-based education. Cambridge Journal of Education, 28(3), 321-331.

Jarvis, P., Holford, J., \& Griffin, C. (2003). The theory and practice of learning (2nd ed.). London: Routledge Falmer. 
Klein, H. K., \& Myers, M. D. (1999). A set of principles for conducting and evaluating interpretive field studies in information systems. MIS Quarterly, 23(1), 67-93.

Knight, P. T. (2001). Complexity and curriculum: A process approach to curriculum-making. Teaching in Higher Education, 6(3), 369-381.

Luckett, K. (2001). A proposal for an epistemically diverse curriculum for South African higher education in the 21 st century. South African Journal of Higher Education, 15(2), 49-61.

Lujan, H. L., \& Dicarlo, S. E. (2006). Too much teaching, not enough learning: What is the solution? Advances in Physiology Education, 30, 17-22.

Moll, I. (2004). Curriculum responsiveness: The anatomy of a concept. In H. Griesel (Ed.), Curriculum responsiveness: Case studies in higher education (pp. 1-19). Pretoria: South African Universities ViceChancellors Association.

Nesbitt, E. (2004). Intercultural education: Ethnographic and religious approaches (1st ed). Brighton: Sussex Academic Press.

Northedge, A. (2003). Enabling participation in academic discourse. Teaching in Higher Education, 8(2), 169-180.

Singh, P. (2002). Pedagogising knowledge: Bernstein's theory of the pedagogic device. British Journal of Sociology of Education, 23(4), 571-582.

Spruell, J. A., \& Le Blanc, L. A. (1992). A course planning method to incorporate collaborative learning in information systems courses. Journal of Information Systems Education, 4(2), 6-11.

Thompson, M. (2008). ICT and development studies: Towards development 2.0. Journal of International Development, 20(6), 821-835.

Toohey, S. (1999). Designing courses for higher education (1st ed.). Buckingham: Society for Research into Higher Education \& Open University Press.

Topi, H., Valacich, J. S., Wright, R. T., Kaiser, K. M., Nunamaker, J. F., Sipior, J. C., \& De Vreede, G. J. (2010). IS2010: Curriculum guidelines for undergraduate degree programs in information systems. New York and Atlanta: Association for Computing Machinery (ACM) and Association for Information Systems (AIS).

Walsham, G. (1995). The emergence of interpretivism in IS research. Information Systems Research, 6(4), 376-394.

Wheelahan, L. (2007). How competency-based training locks the working class out of powerful knowledge: A modified Bersteinian analysis. British Journal of Sociology of Education, 28(5), 637651.

Zheng, Y. (2009). Different spaces for e-development: What can we learn from the capability approach? Information Technology for Development, 15(2), 66-82.

\section{Biography}

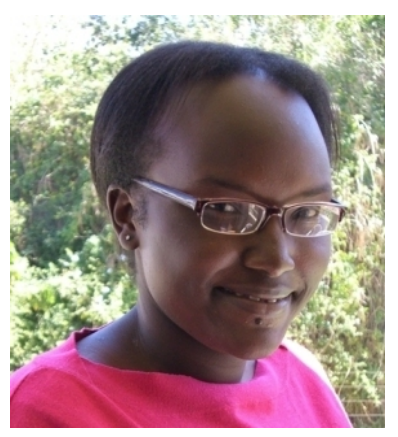

Dr Caroline Pade Khene is a Senior Lecturer in the Department of Information Systems at Rhodes University, South Africa. Her primary research interests are in information and communication technology in developing countries, focusing on evaluation and project management; and higher education in developing countries. Caroline holds a Bachelor's Degree in Business Science, a Masters and $\mathrm{PhD}$ in Information Systems, and a Postgraduate Diploma in Higher Education. 


\section{Appendix}

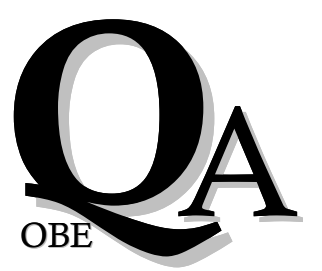

Department of Information Systems

Rhodes University

\section{Module Specification Document}
Module name Information and Communication Technology for De- velopment

Module short ICT4D

name/acronym

Owner

Moderator(s)

File name

Courses level(s) IS Honours

\begin{tabular}{|c|c|c|c|}
\hline $\begin{array}{c}\text { Version } \\
\mathrm{N}^{\mathrm{O}}\end{array}$ & Date & Modified by & Description of changes \\
\hline 1 & October 2011 & & New document \\
\hline 2 & July 2013 & & Updated \\
\hline
\end{tabular}




\section{Contents}

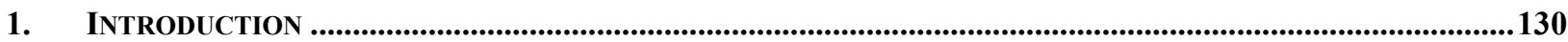

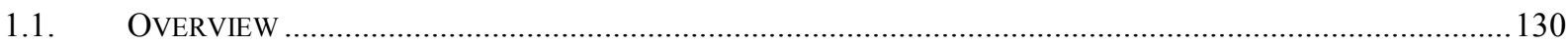

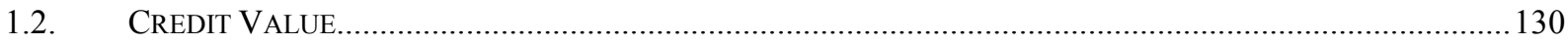

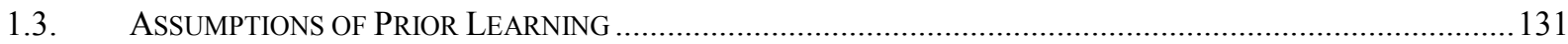

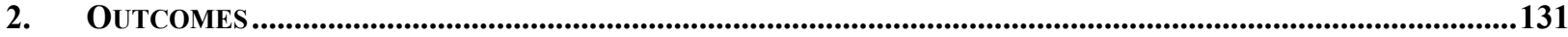

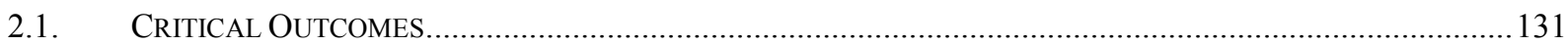

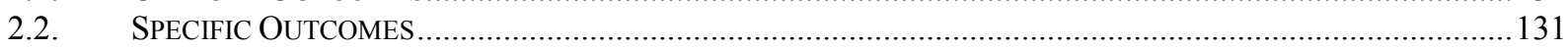

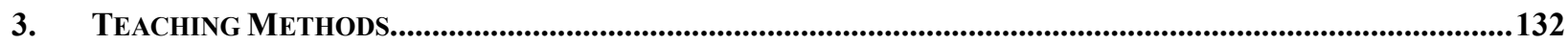

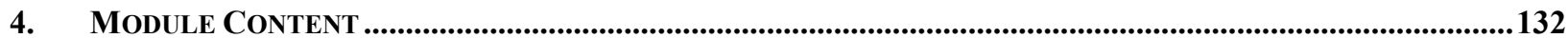

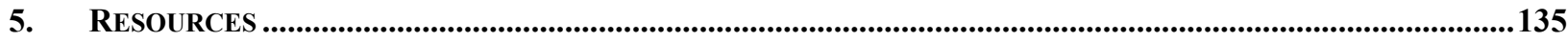

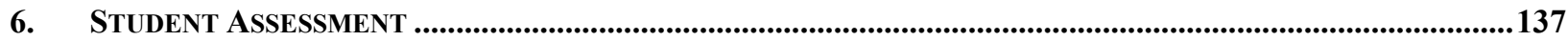

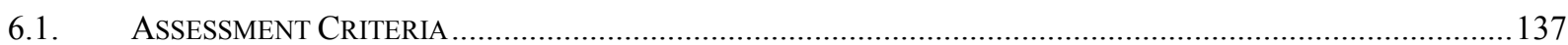

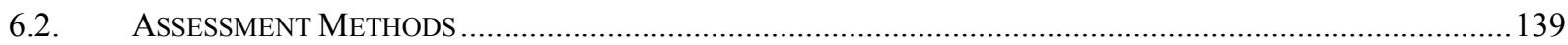

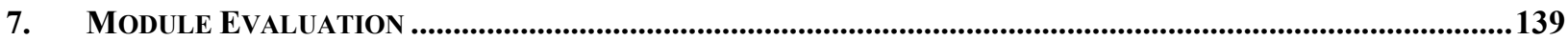




\section{INTRODUCTION}

\subsection{OVERVIEW}

ICT for Development (ICT4D) is a field that explores how information and communication technologies (ICT) can be used to enable or support development activities in developing countries. ICTs can broadly be defined as tools that aid in the communication between people, through means of capturing, processing, storing, and communicating information. They consist of hardware and software, network appliances (Internet), radio, television, mobile phones, as well as services and applications associated with, for example, e-health, elearning and e-governance.

ICT4D is commonly known as a multidisciplinary field, encompassing information systems, computer science, and socio-economic development studies. The changing nature of the information systems field has also opened the way for other disciplines, such as, health, education, and government. Rhodes University exists in a developing country, and is surrounded by marginalised communities, and emerging local businesses. The university is surrounded by rural communities and towns confronted with challenging social, cultural and economic conditions. Understanding the potential and impact of ICT is a core academic area that students can engage with, exploring how to use their information systems (IS) skills to identify and recommend practices to address these challenges in their own country's context. It is essential to understand how the IS discipline can contribute to addressing development challenges faced in South Africa, as government and development organisations continuously explore supporting solutions for development, and business organisations explore emerging markets in developing countries.

The aim of this module is to introduce students to the fundamental concepts and discourse of the ICT4D field. Focus is placed on project management and evaluation, toward supporting the sustainability of ICT4D projects in developing countries. Since ICT4D is a multidisciplinary field, the module attempts to integrate concepts of information systems, computer science, and socioeconomic development studies.

"A module responsive to African realities"

\subsection{Credit Value}

This module is worth $10 \%$ of IS Honours / 4th Year Course.

\begin{tabular}{lccc} 
& $\begin{array}{c}\text { Number of lec- } \\
\text { tures/sessions }\end{array}$ & $\begin{array}{c}\text { Hours per lec- } \\
\text { ture/session }\end{array}$ & $\begin{array}{c}\text { Total number } \\
\text { of hours }\end{array}$ \\
\hline Lectures & 20 & 1 & 20 \\
Practicals - formal & & - & - \\
Practicals - self study & & - & -
\end{tabular}


Term Tests

Practical Examination

TOTAL

\subsection{Assumptions Of Prior LeARning}

Students are required to have gained prior credit in Information Systems 3 in which they would have developed knowledge of:

- Corporate Communications, to engage and work in teams, and provide presentations to the class.

- Project management, to understand the application of concepts of project management and evaluation in ICT4D projects.

- A general background understanding of the information systems discipline, to identify how it may be applied in the ICT4D field.

\section{OUTCOMES}

\subsection{Critical Outcomes}

Students will be expected to:
a. identify and solve problems
b. work in a team
c. organise and manage him/herself
d. collect, analyse and evaluate information
e. communicate effectively
f. recognise problem solving contexts
g. reflect on and explore effective learning strategies
h. participate as a responsible citizen
i. be culturally and aesthetically sensitive

\subsection{SPECIFIC OUTCOMES}

At the conclusion of the module, students should be able to:

a. Describe the concepts of Development and Rural Development

b. Discuss the role of ICTs in Development - ICT for Development

- Describe the Uses and Challenges of ICTs in developing country contexts (urban and/or rural)

c. Discuss the key Trends in ICT for Development - from ICT4D 1.0 to ICT4D 2.0

d. Explore key issues of Sustainability associated with ICT4D projects

e. Identify key project management practices in ICT4D projects

f. Discuss Ethical practice in ICT4D interventions 
g. Describe how to conduct a comprehensive evaluation of ICT4D projects, to guide implementation and assess impact.

\section{Teaching Methods}

This module is delivered via formal lessons, class discussions or debates, paper readings and case study assignments.

- Daily lessons (2 hours each day) over a two (2) week period are given to explain the content as well as provide real-life examples experienced by the lecturer. In addition, invited guest lectures will be provided by stakeholders and researchers who are currently participating members of an ICT4D project.

- Each lesson is supported by discussions or debates of selected research paper readings related to the lecture topic. This will enable critical thinking, problem solving, and collaborative exercises to understand and engage with the ICT4D discipline. Furthermore, it will accommodate for unexpected learning outcomes that emerge in class discussions. Students will be required to complete readings before each lecture and self-reflective journal tasks after each lecture session. The on-line Learning Management System, RUConnected, will be used to provide course content and reading lists. In addition, students can access their on-line journal to reflect on the discussions and debates during a lecture session (the lecturer will ask questions to guide the self-reflective exercise).

- One (1) group based Case Study assignment.

\section{Module Content}

Theory Content is of a theoretical and practical nature which supports the practical assignments of the module.

\section{Theory Content}


Defining ICT4D. This section presents the field of ICT4D.

This section also introduces the concepts of development, rural development and the importance of information in supporting the development process.

Assignment 1 is presented

2 The Role of ICT in Development

Various concepts are defined and the role of Information and Communication in development is discussed. A debate on the investment of ICT in development, verses other essential resources in development will also support the lecture.
Paper 1; \& Lec-

ture $1 \& 2$ Series

Handout (pg 7-

10);

\section{The Uses and Challenges of ICT4D}

This section discusses the general uses and challenges of ICT4D in the developing country context. Uses and challenges may vary with the technology used (e.g. computers vs. mobile phones), which will be considered and discussed as a collaborative exercise in the class.

3 Trends in ICT4D

This section discusses the trends and debates in ICT4D resulting in a transition from ICT4D 1.0 to ICT4D 2.0.

Assignment 2 in Class: Trends towards ICT4D 3.0
Course hand-out

Readings: $\mathrm{Pa}$ -

pers 2

\section{$4 \quad$ Sustainability in ICT4D}

This section presents the importance of sustainability in ICT4D programmes. The critical success factors and categories of sustainability are discussed, which include social and cultural, institutional, economic/financial, political, and technological.
Course hand-out

Readings:

Paper 3

$5 \quad$ Project Management Practice in ICT4D Projects

Course hand-out

This section discusses different frameworks or models that explain the phases that an ICT4D project goes through. Three particular frameworks are discussed, that is, the ICT4D Value Chain, the Process Approach and the Rural ICT Project Lifecycle (RICT-PLC).

\section{Ethical Practice in ICT4D}

Paper 4

This section discusses aspects to consider when implementing and introducing ICT4D interventions in developing country contexts

6 Comprehensive Evaluation of ICT4D projects

This section introduces the significance of evaluation throughout the lifecycle of ICT4D projects at a micro-level. The changing trends in evaluation are discussed and critiqued. Finally, the Rural ICT Comprehensive Evaluation FrameReadings: Lecture 5 series work (RICT-CEF) is presented.

Guest Lecture: Hafeni Mthoko

Impact Assessment with a Comprehensive View 
7 Guest Lecture:

Kirstin Krauss

Topic: to be confirmed

$8 \quad$ Guest Lecture: Lessons Learned

Prof Hannah Thinyane

MobiSAM Project - Mobile Social Accountability Monitoring

$9 \quad$ Case Study Presentation

3 Groups present on the application of the RICT-PLC in a Case Study. This will include a background on the case study, and key project management practices applied in the case study.

The Way Forward

Final lecture that sums up the module, and discusses the exam

\section{Readings}

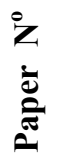

Title

1 Unwin, T. (2009). ICT4D: Information and Communication Technology for Development. Cambridge: Cambridge University Press - Chapter 3: Information and Communication in Development Practices (Pages 39 - 75)

2 Heeks, R. (2009). The ICT4D 2.0 Manifesto: Where Next for ICTs and International Development? Manchester: Institute for Development Policy and Management. [Online]. Available:

http://www.sed.manchester.ac.uk/idpm/research/publications/wp/di/documents/di_wp42.pdf

3 Pade, C., Mallinson, B., and Sewry, D. (2008). An Elaboration of Critical Success Factors for Rural ICT Project Sustainability in Developing Countries - Exploring the Dwesa Case. The Journal of Information Technology Case and Application (JITCAR), 10, 4.

$4 \quad$ Mthoko, H. L. W. T. and Pade-Khene, C. (2012). Towards a Theoretical Framework on Ethical Practice in ICT4D Programmes. Information Development Journal. Read pg 13-15.

5 Pade, C. and Sewry, D (2009). The Practice and Need for Rural ICT for Development Evaluation: An Experience of the Siyakhula Living Lab Baseline Study. $3^{\text {rd }}$ International Development Informatics Association (IDIA) Conference. Digitally Empowering Communities: Learning from Development Informatics Practice. Kruger National Park, South Africa, October 2009.

$6 \quad$ Pade-Khene, C. and Sewry, D. (2011). Proposed Stages of a Rural ICT Comprehensive Evaluation Framework in ICT for Rural Development Projects. SAICSIT 2011, Annual Conference of the South African Institute of Computer Scientists and Information Technologists, Cape Town, South Africa, October 2011. 


\section{Project Assignments}

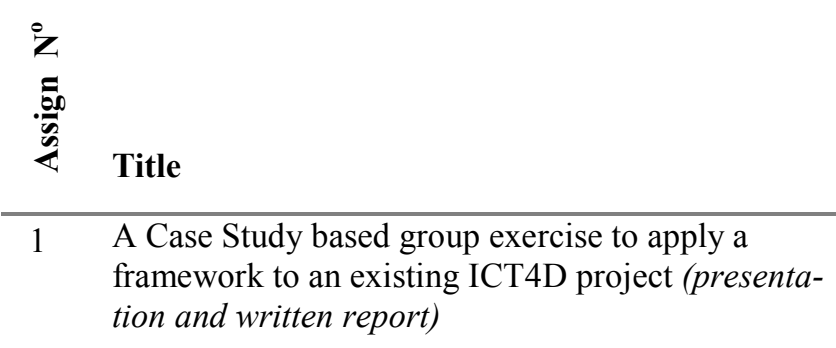

\section{Activities}

Students are required to explore an ICT4D case study, based on a set of readings. In addition, they are required to apply the Rural ICT Project Life Cycle (RICT-PLC) Framework to assess the strengths and weaknesses of a project in applying sustainable project management practices.
2 An innovative group discussion to determine what will constitute ICT4D 3.0 (discussion in class)
Question: What, if anything, might constitute "ICT4D 3.0"? Can we gain anything by trying to look so far ahead on the curve?

Students are required to work in groups to identify trends in ICT4D and/or propose their own ideologies into trends. They will be required to apply their knowledge of Information Systems, as well as, other supporting disciplines in ICT4D, such as, computer science, management, development studies, etc. The best innovative ideas will win a prize.

\section{RESOURCES}

\section{Recommended (Optional) readings:}

- Bridges (2006) 12 Habits of Highly Effective ICT-Enabled Development Initiatives. Bridges.Org. [Online]. Available: http://www.bridges.org/12_habits

- Chapman, R. and Slaymaker, T. (2002). ICTs and Rural Development: Review of the Literature, Current Interventions and Opportunities for Action. Working Paper 19, Overseas Development Institute, London. [Online]. Available:

http://www.odi.org.uk/publications/working_papers/wp192.pdf

- Harris, R., W. (2004). Information and Communication Technologies for Poverty Alleviation. Kuala Lumpur: United Nations Development Programmes Asia Pacific Development Information Programme (UNDP-APDIP). [Online] Available: http://www.apdip.net/publications/iespprimers/eprimer-pov.pdf

- Harris, R. W. (2007). Telecentre Evaluation in the Malaysian Context. Proceedings of the 5th International Conference on IT in Asia, 10-12 July 2007, Kuching, Sarawak, Malaysia.

- Heeks, R. and Molla, A. (2008). Compendium on Impact Assessment of ICT-for- 
Development Projects. Manchester: Institute for Development Policy and Management. [Online]. Available:

http://www.sed.manchester.ac.uk/idpm/research/publications/wp/di/di_wp36.htm

- International Development Research Centre (IDRC) (2003). Opportunities and Challenges for Community Development: Information and Communication Technologies for Development in Africa, vol. 1, 2003. Jointly published by Ottawa: IDRC and Dakar: Council for the Development of Social Science Research in Africa (CODESRIA).

- Mansell, R. and Wehn, U. (1998). Knowledge Societies: Information Technology for Sustainable Development (1e). New York: Oxford University Press.

- Meyer, H. W. J. (2002). Information as a Resource for Rural Development. Mousaion. 20, 1: 93-108.

- Mulder, I., Bohle, W., Boshomane, S., Morris, C., Tempelman, H. and Velthausz, D. (2008). Real World Innovation in Rural South Africa. The Electronic Journal for Virtual Organisations and Networks, 10: 8-20.

- Pade, C., Mallinson, B., and Sewry, D. (2006). An Exploration of the Categories Associated with ICT Project Sustainability in Rural Areas of Developing Countries: A Case Study of the Dwesa Project. SAICSIT 2006, Annual Conference of the South African Institute of Computer Scientists and Information Technologists, Gordon's Bay, Western Cape, October 2006.

- Pade, C., Mallinson, B., and Sewry, D. (2008). Project Management Practice for Rural ICT Project Sustainability in Developing Countries. 2nd European Conference on Information Management and Evaluation (ECIME). Royal Holloway, University of London. ISBN: 978-1-906638-13-9 CD.

- Pade-Khene, C., Palmer, R. and Kavhai, M. (2010). A Baseline Study of the Dwesa Rural Community for the Siyakhula Information and Communication Technology for Development Project: Understanding the Reality on the Ground. Information Development. 26, 4.

- Pade-Khene, C., Mallinson, B., and Sewry, D. (2011). Sustainable Rural ICT Project Management Practice for Developing Countries: Investigating the Dwesa and RUMEP Projects. Special issue on 'Information Technology Success Factors and Models in Developing and Emerging Economies'. Journal of Information Technology for Development. 17, 3: 187-212.

- Schwalbe, K. (2006). Information Technology Project Management (4e). Boston, Massachusetts: Thomson Course Technology.

- Thompson, M. (2008). ICT and Development Studies: Towards Development 2.0. Journal of International Development. 20: 821-835.

- Toyama, K. (2011). Technology as Amplifier in International Development. iConference 2011. Seattle, WA, United States of America.

- Unwin, T. (2009). ICT4D: Information and Communication Technology for Development. Cambridge: Cambridge University Press - Chapter 2: Development Agendas and the place for ICTs (Pages 7 - 38)

- Walton, M. and Heeks, R. (2011). Can a Process Approach Improve ICT4D Project Success. Manchester: Institute for Development Policy and Management. [Online]. Available:

http://www.sed.manchester.ac.uk/idpm/research/publications/wp/di/index.htm

\section{Other reference material:}


- ICT4D Course Handout

- ICT4D Course Lecture slides

\section{Student Assessment}

\subsection{Assessment Criteria}

\begin{tabular}{|c|c|c|c|}
\hline 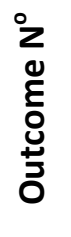 & Specific Outcomes & Assessment Criteria & Assessment Tasks \\
\hline 1 & $\begin{array}{l}\text { Understand the concepts of } \\
\text { Development and Rural De- } \\
\text { velopment }\end{array}$ & $\begin{array}{l}\text { a. Explain the need for devel- } \\
\text { opment and rural develop- } \\
\text { ment in developing countries. } \\
\text { b. Discuss the importance of } \\
\text { information, knowledge and } \\
\text { communication in supporting } \\
\text { the socio-economic develop- } \\
\text { ment process. }\end{array}$ & $\begin{array}{l}\text { Formative } \\
\text { - Presentation and dis- } \\
\text { cussions around read- } \\
\text { ings } \\
\text { - Self-reflective journal } \\
\text { Summative } \\
\text { - Theory exam ques- } \\
\text { tions }\end{array}$ \\
\hline 2 & $\begin{array}{l}\text { Understand the role of ICTs } \\
\text { in Development - ICT for } \\
\text { Development: }\end{array}$ & $\begin{array}{l}\text { a. Define and discuss the con- } \\
\text { cept of ICT for development. } \\
\text { b. What is the justification for } \\
\text { ICT4D? } \\
\text { c. Discuss the relationship be- } \\
\text { tween development, infor- } \\
\text { mation and ICTs. } \\
\text { d. Describe uses of ICT in sup- } \\
\text { porting socio-economic de- } \\
\text { velopment. } \\
\text { e. Describe the challenges asso- } \\
\text { ciated with the implementa- } \\
\text { tion, use, and sustainability of } \\
\text { ICTs in supporting socio- } \\
\text { economic development. }\end{array}$ & $\begin{array}{l}\text { Formative } \\
\text { - Presentation and dis- } \\
\text { cussions around read- } \\
\text { ings } \\
\text { - Self-reflective journal } \\
\text { Summative } \\
\text { - Theory exam ques- } \\
\text { tions }\end{array}$ \\
\hline 3 & $\begin{array}{l}\text { Discuss the key Trends in } \\
\text { ICT for Development - from } \\
\text { ICT4D } 1.0 \text { to ICT4D } 2.0\end{array}$ & $\begin{array}{l}\text { a. Describe the identified chro- } \\
\text { nology from ICT4D } 0.0 \text { to } \\
\text { ICT4D 2.0. } \\
\text { b. What are the identified tech- } \\
\text { nological priorities for ICT4D } \\
2.0 ? \\
\text { c. Discuss the identified innova- } \\
\text { tion models for ICT4D 2.0? } \\
\text { d. Discuss the identified } \\
\text { worldviews impinging on } \\
\text { ICT4D, and how should they }\end{array}$ & $\begin{array}{l}\text { Formative } \\
\text { - Presentation and dis- } \\
\text { cussions around read- } \\
\text { ings } \\
\text { - Assignment 1: Inno- } \\
\text { vative Thinking Exer- } \\
\text { cise } \\
\text { Summative } \\
\text { - Applied Theory exam } \\
\text { questions }\end{array}$ \\
\hline
\end{tabular}




\begin{tabular}{|c|c|c|c|c|}
\hline & & & $\begin{array}{l}\text { be handled in ICT4D } 2.0 ? \\
\text { What, if anything, might con- } \\
\text { stitute "ICT4D 3.0"? Can we } \\
\text { gain anything by trying to } \\
\text { look so far ahead on the } \\
\text { curve? }\end{array}$ & \\
\hline 4 & $\begin{array}{l}\text { Describe key issues of Sus- } \\
\text { tainability associated with } \\
\text { ICT4D projects }\end{array}$ & $\begin{array}{l}\text { a. } \\
\text { b. } \\
\text { c. } \\
\text { d. }\end{array}$ & $\begin{array}{l}\text { Describe the levels of ICT } \\
\text { project failure. } \\
\text { Explain the concept of Sus- } \\
\text { tainability. } \\
\text { Discuss the various categories } \\
\text { of sustainability that influ- } \\
\text { ence the success of rural ICT } \\
\text { projects. } \\
\text { Identify and describe the crit- } \\
\text { ical success factors of sus- } \\
\text { tainability for rural ICT4D } \\
\text { projects. }\end{array}$ & $\begin{array}{l}\text { Formative } \\
\text { - Presentation and dis- } \\
\text { cussions around read- } \\
\text { ings } \\
\text { - Self-reflective journal } \\
\text { Summative } \\
\text { - Theory exam ques- } \\
\text { tions }\end{array}$ \\
\hline 5 & $\begin{array}{l}\text { Identify key project manage- } \\
\text { ment practices in ICT4D pro- } \\
\text { jects } \\
\text { Discuss Ethical practice in } \\
\text { ICT4D interventions }\end{array}$ & $\begin{array}{l}\text { a. } \\
\text { b. } \\
\text { c. } \\
\text { d. } \\
\text { e. }\end{array}$ & $\begin{array}{l}\text { Describe the ICT4D Value } \\
\text { Chain } \\
\text { Explore the Process Ap- } \\
\text { proach to ICT4D implemen- } \\
\text { tation. } \\
\text { Describe the phases (and as- } \\
\text { sociated practices) of the Ru- } \\
\text { ral ICT Project Lifecycle in a } \\
\text { case study. } \\
\text { Explore key practices of the } \\
\text { RICT-PLC in an existing } \\
\text { ICT4D project case study. } \\
\text { Identify and describe the } \\
\text { themes of ethical practice in } \\
\text { ICT4D projects. }\end{array}$ & $\begin{array}{l}\text { Formative } \\
\text { - Presentation and dis- } \\
\text { cussions around read- } \\
\text { ings } \\
\text { - Assignment 2: Case } \\
\text { Study Exercise } \\
\text { Summative } \\
\text { - Applied Theory exam } \\
\text { questions based on a } \\
\text { Case Study }\end{array}$ \\
\hline 6 & $\begin{array}{l}\text { Describe how to conduct a } \\
\text { comprehensive evaluation of } \\
\text { ICT4D projects, to guide im- } \\
\text { plementation and assess im- } \\
\text { pact. }\end{array}$ & $\begin{array}{l}\text { a. } \\
\text { b. } \\
\text { c. } \\
\text { d. }\end{array}$ & $\begin{array}{l}\text { Discuss the need for evalua- } \\
\text { tion in ICT4D. } \\
\text { Describe the emerging trends } \\
\text { of ICT4D evaluation. } \\
\text { Discuss the shortcomings and } \\
\text { challenges of ICT4D evalua- } \\
\text { tion. } \\
\text { Present the Rural ICT Com- } \\
\text { prehensive Evaluation } \\
\text { Framework (RICT-CEF). }\end{array}$ & $\begin{array}{l}\text { Summative } \\
\text { - Theory exam ques- } \\
\text { tions. Some Applied } \\
\text { Theory exam ques- } \\
\text { tions may be relevant. }\end{array}$ \\
\hline
\end{tabular}




\subsection{Assessment Methods}

Formative

Discussions around readings, Innovative Thinking Exercise.

\section{Summative}

- Case Study application of the Rural ICT Project Life Cycle (RICT-PLC) Framework

- One 3 hour final theoretical examination that includes practical application questions (The exam is partially open book)

\section{Weighting Factors}

\begin{tabular}{lrr} 
& $\begin{array}{r}\text { \% of Class } \\
\text { Mark }\end{array}$ & $\begin{array}{r}\text { \% of IS Hons } \\
\text { Course Mark }\end{array}$ \\
\hline Class Assignments & 30 & \\
Theory Examination & 70 & $10 \%$
\end{tabular}

\section{Module Evaluation}

An evaluation will be conducted before the course, and at the end of the course. This will be qualitative through class discussions and observations by the lecturer. 